\title{
The Aicardi Syndrome: Report of 4 Cases and Review of the Literature
}

\author{
John M. Bertoni, MD, Siegrun von Loh, MD, and Richard J. Allen, MD
}

The findings in 4 cases of Aicardi syndrome (female infants with mental retardation, seizures, characteristic eye lesions, agenesis of the corpus callosum, vertebral anomalies, and abnormal but nondiagnostic electroencephalographic patterns) are compared to 39 previously reported cases. Available information suggests that the syndrome results from an unknown intrauterine insult occurring no later than the first trimester. No familial cases have been reported, and the cause remains unknown.

Bertoni JM, von Loh S, Allen RJ: The Aicardi syndrome: report of 4 cases and review of the literature. Ann Neurol 5:475-482, 1979)

In 1965 Aicardi et al [3] described a syndrome consisting of "spasms in flexion," agenesis of the corpus callosum, and multiple ocular anomalies occurring in retarded female infants. Other associated findings in subsequent patients have included porencephalia, cortical heterotopias, facial asymmetry, rib and vertebral dysplasias, and scoliosis. In addition to Aicardi's cases [1-3] there have been several other clinical reports $[8-13,19,22,24,26,30,31,33,35$, 39]; nearly all have been in the non-English literature, and only Fariello et al [11] have reported more than 3 such patients (although agenesis of the corpus callosum was well documented and complete in only 3 of their 6 patients). The present series thus represents the largest collection of the complete syndrome reported since Aicardi's original description.

\section{Case Reports \\ Patient 1}

An infant girl was the product of an unremarkable gestation (except for transient skin rash and albuminuria) and delivery. At birth, severe right microphthalmia and dysplasia of the left retina were noted. At 2 weeks of age the baby developed spells of eye rolling, eyelid twitching, extension of the extremitics, and mild cyanosis. Roentgenograms demonstrated normal skull and forearms but multiple thoracic vertebral anomalies. The head progressively enlarged, and a ventriculogram showed agenesis of the corpus callosum and multiple cortical heterotopias. An electroencephalogram was moderately abnormal with a paroxysmal epileptogenic focus in the left hemisphere. At 3 months of age a ventriculoatrial shunt was inserted due to increasing head size.

From the Section of Pediatric Neurology, Department of Pediatrics, and the Department of Neurology. University of Michigan Medical Center, Ann Arbor, MI.

Accepted for publication Sept 11, 1978
At the age of 29 months, a follow-up examination revealed an unresponsive child in decerebrate posture with torticollis and poor handling of oral secretions. There was generalized chorioretinitis on the left. The electroencephalogram was profoundly abnormal, with a burst-suppression pattern.

\section{Patient 2}

An infant girl was the product of a term pregnancy marked by "stomach cramps," headaches, and vaginal discharge. Labor was induced 48 hours after rupture of the membranes. At 10 weeks, the patient began to have headbobbing spells up to 100 times per day, with tonic-clonic movements and eye deviation to the left. Right microphthalmia and extensive bilateral chorioretinitis (Fig 1) were seen. Roentgenograms showed brachycephaly and variations in size of the lumbar vertebrae. A pneumoencephalogram revealed agenesis of the corpus callosum and heterotopias adjacent to dilated lateral ventricles. The EFG was markedly and diffusely abnormal, with frequent spike-wave and polyspike-wave bursts consistent with hypsarrhythmia and a burst-suppression pattern. The seizures persisted despite a regimen of phenobarbital, $30 \mathrm{mg}$ daily, phenytoin, $15 \mathrm{mg}$ daily, and prednisone, $15 \mathrm{mg}$ daily.

\section{Patient 3}

A rerm female infant required forceps delivery after 32 hours of labor. At 11 weeks she developed daily convulsions consisting of cyclic flexion of the extremities for several seconds; these convulsions were not controlled with phenobarbital, $40 \mathrm{mg}$ per day. At 14 weeks, examination revealed normocephaly, bilateral chorioretinitis, right exotropia, and hypotonia. Roentgenograms showed a normal skull but multiple thoracic spinal anomalies. A

Address reprint requests to Dr Bertoni, Department of Neurology, University of Michigan Medical Center, Ann Arbor, MI 48109 . 


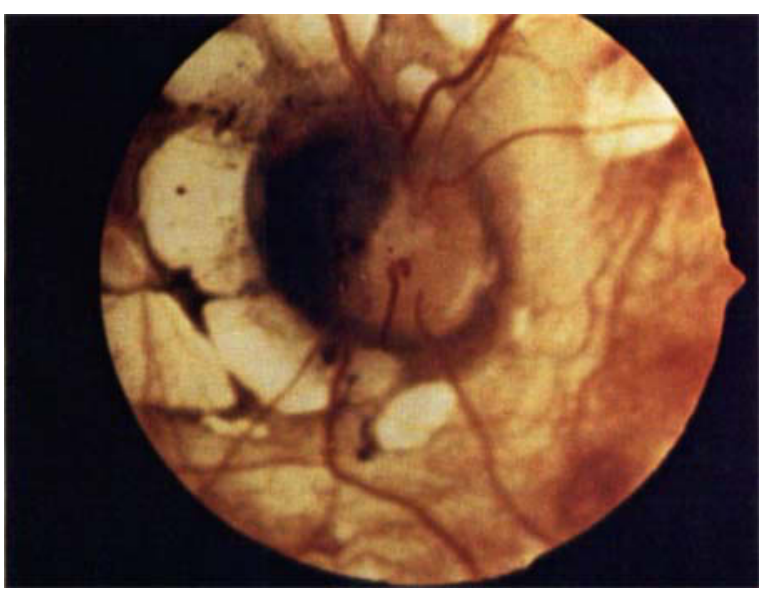

Fig 1. Left ocular fundur of Patient 2. Multiple "punchedout" patches. some as large as one-half disc diameter. of geographic atrophy of the retinal pigment epithelium and choroid are scattered around the disc. Mild dysplasia of the optic nerve bead and anomalous branching of rentral retinal versels are also seen.

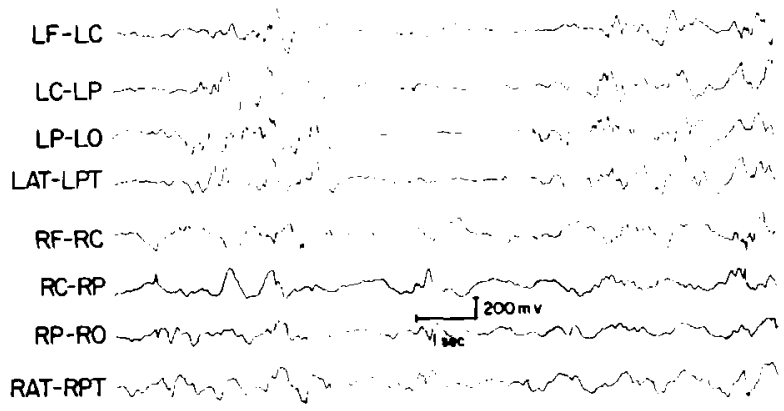

Fig 2. Electroencephalogram of Patient 3. age 3 months. The tracing shou's a burst-suppression pattern. expecially on the left side. High-ioltage slow components uith shifting sharp discharges can be seen on the right side. (Bandpass. 1 to $30 \mathrm{~Hz}$.) $(\mathrm{I} .=$ left $: \mathrm{R}=$ right $: \mathrm{F}=$ frontal: $\mathrm{C}=$ central: $\mathrm{P}=$ parietal: $\mathrm{O}=$ ocapital: $\mathrm{AT}=$ anterior temporal: $\mathrm{PT}=$ posterior temporal.)

pneumoencephalogram revealed total agenesis of the corpus callosum.

The EEG (Fig 2) demonstrated hypsarrhythmia and a burst-suppression pattern. Seizures were not controlled by $10 \mathrm{mg}$ of phenytoin daily, $40 \mathrm{mg}$ of phenobarbital daily, and $375 \mathrm{mg}$ of acetazolamide daily. At 12 months the head circumference was smaller than 3 standard deviations under the mean, and the infant was unable to roll over and had no speech. The EEG showed marked abnormalities, with numerous spike-wave bursts and delta waves up to $200 \mu \mathrm{v}$ in amplitude, and marked hemisphere bisynchrony.

\section{Patient 4}

A baby girl was the term product of a pregnancy complicated by first-trimester edema of the hands and feet. At 4 weeks of age the baby developed spells of heavy breathing and repetitive 2- to 3-second episodes of flexion of the neck

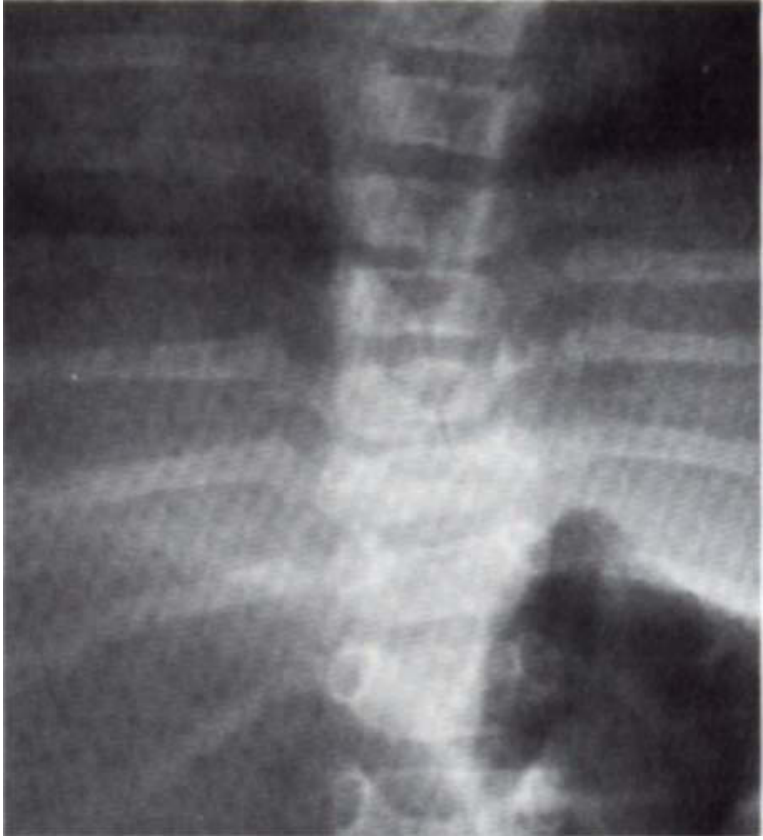

Fig 3. Frontal lieu roentgenogran of thoracic spine of Patient 4. Note the minimal rotoscoliosic and spina bifida orculta of the posterior neural arbes at multiple levels.

and elbows and extension of the lower extremities, with eye deviation to the right. Despite therapy with phenytoin, $100 \mathrm{mg}$ daily, and primidone, $240 \mathrm{mg}$ daily, up to $50 \mathrm{such}$ spells occurred per day. At 4 months, examination showed normocephaly, generalized hypotonia, and multiple sharply demarcated areas of retinal pigmentary degeneration bilaterally. Skull roentgenograms were normal, but multiple anomalies (e.g., unfused neural arches, scoliosis) were noted on thoracic spine films (Fig 3). The EEG was profoundly and diffusely abnormal, with high-amplitude (over $500 \mu v$ ) spike-wave bursts consistent with hypsarthythmia with a burst-suppression pattern. Seizures were reduced to three per day with prednisone, $30 \mathrm{mg}$ per day, phenytoin, $25 \mathrm{mg}$ per day, primidone, $50 \mathrm{mg}$ per day, and acetazolamide, $250 \mathrm{mg}$ per day. At 12 months the head circumference was smaller than 3 standard deviations below the mean, and a pneumoencephalogram showed complete agenesis of the corpus callosum with nodular indentation of the lateral ventricles ( $\mathrm{Fig} 4$ ). At 2 years the patient was able to stand with support; at $4 \frac{1 / 2}{2}$ years she still could not stand alone and had only babbling speech. She had been seizure-free for over a year. At age 5 years 10 months, a CT scan (Fig 5) revealed multiple anomalies, including apparent absence of the corpus callosum and a bizarrely shaped ventricular system.

\section{Discussion}

Table 1 summarizes the cardinal features of the Aicardi syndrome in previously reported cases plus our 4 patients. The complete syndrome includes female sex, mental retardation, seizures, eye lesions, agenesis of the corpus callosum, costovertebral 


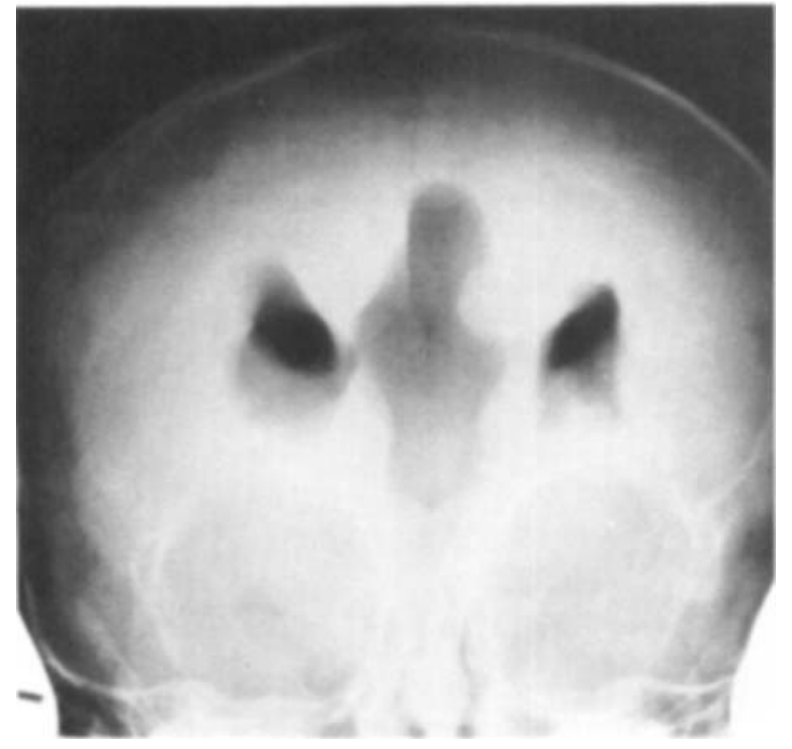

Fig 4. Pnenmoencephalogram of Patient 4. Frontal rieu' in the "pright position demonstrates typical appearanse of ageneris of the corpus callosum. with nodular indentation of the ceniricular sytem comsissent with heterotopias.

Fig 5. C7 scan of Patiems 4 . with sections in the regions of the third rentride (left) and lateral rentriles (right). A midline brain malformation uith agenesis of the corpus iallosmm and innsiderable enla rkement and irregularity of the ientricular system are demonstrated.

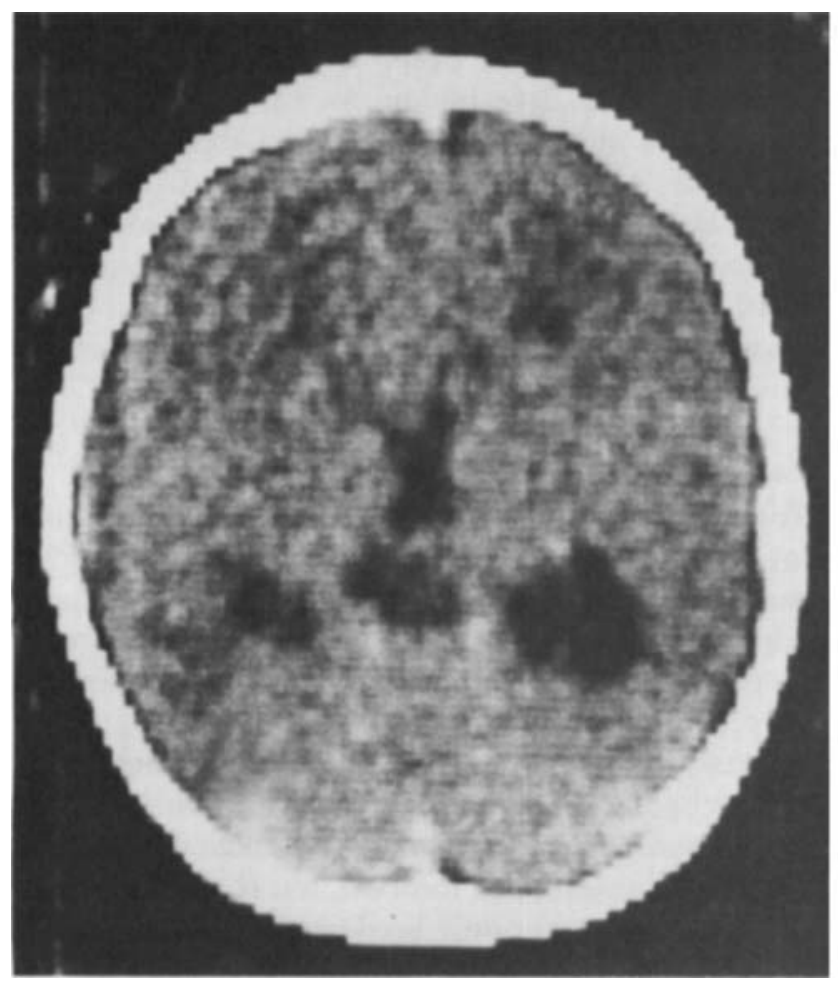

anomalies, and abnormal but nondiagnostic EEG findings with otherwise unremarkable laboratory tests and family history. Analysis of these individual clinical features suggests certain etiological possibilities.

\section{Sex of Patients}

All patients with the Aicardi syndrome are at least phenotypically female. Although this may have pathogenetic significance, its meaning remains unclear. Karyograms have been done in 11 patients, and all were normal.

\section{Mental Retardation}

All patients thus far reported with the Aicardi syndrome have had severe mental retardation with delayed psychomotor milestones. Few reports provide follow-up studies of psychomotor development. Two 4-year-old girls were reported as being unable to walk $[11,30]$ and a 6-year-old girl was described as being severely retarded and without reaction to her surroundings [39]. Only 1 of our patients (No. 4) was able to stand with support at the age of 2 years. There was a notable relationship between the severity of muscular hypotonia and the degree of mental retardation, which may indicate that in these patients the pathological changes of muscle tone are secondary to the cerebral dysfunction. Mental retardation and seizures (unspecified) have also been reported in simple agenesis of the corpus callosum $[5,36]$, but more often there are no clinically detected abnormalities.

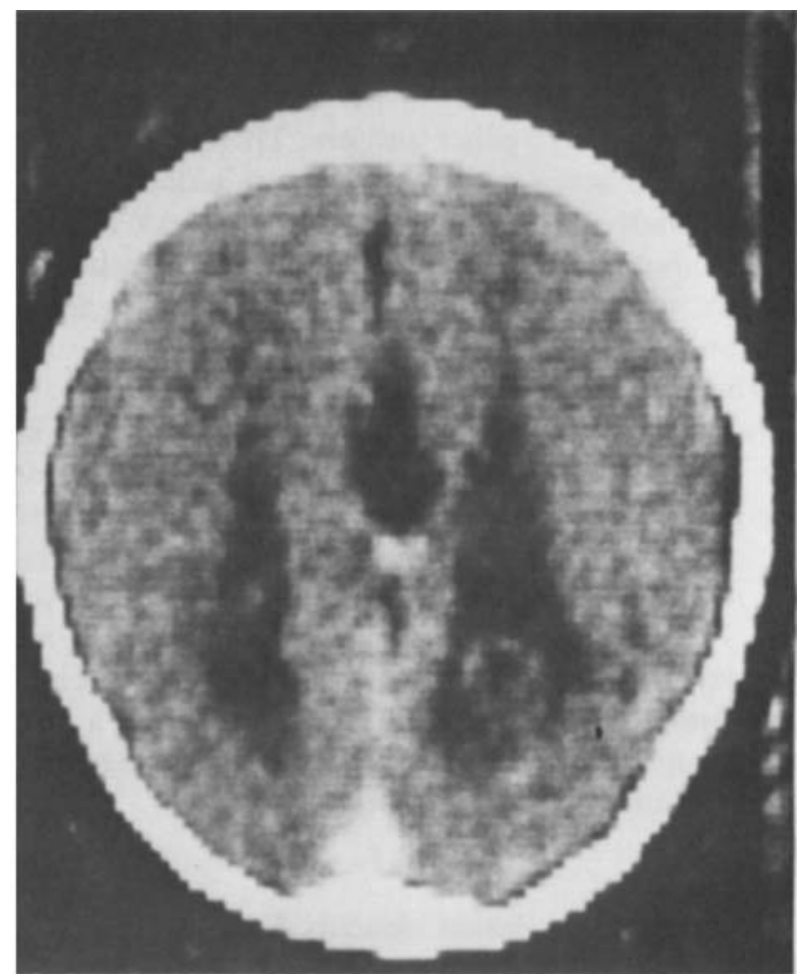




\begin{tabular}{|c|c|c|c|c|c|c|c|c|c|c|c|c|c|c|c|}
\hline \multirow[b]{3}{*}{ Authors and Year } & \multirow[b]{3}{*}{$\mathrm{N}$} & \multirow[b]{3}{*}{$\mathrm{F}$} & \multirow[b]{3}{*}{ MR } & \multirow[b]{3}{*}{ Seiz } & \multicolumn{4}{|c|}{ Eye Lesions } & \multicolumn{3}{|c|}{ PEG Findings } & \multirow{2}{*}{\multicolumn{2}{|c|}{ Spine Lesions }} & \multirow{2}{*}{\multicolumn{2}{|c|}{ EEG Findings }} \\
\hline & & & & & \multicolumn{2}{|c|}{$\mathrm{CR}$} & \multirow[b]{2}{*}{$\mathrm{Col}$} & \multirow[b]{2}{*}{ MiC } & \multicolumn{2}{|c|}{$\mathrm{ACC}$} & \multirow[b]{2}{*}{ Het } & & & & \\
\hline & & & & & Bil & Uni & & & Tot & Par & & Hemi & Other & Hyps & B-S \\
\hline $\begin{array}{l}\text { Aicardi et al [1-3], } 1965 \text {, } \\
\quad 1968,1969\end{array}$ & 15 & 15 & 15 & 15 & 14 & 1 & 7 & 4 & 13 & 2 & 15 & 1 & 9 & 10 & 4 \\
\hline Léman et a] [19], 1968 & 1 & 1 & 1 & 1 & & 1 & & & & 1 & & & & & \\
\hline Saraux et al [35], 1969 & 1 & 1 & 1 & 1 & 1 & & & & 1 & & & 1 & & 1 & \\
\hline $\begin{array}{l}\text { Rousselie and Fontaine [3.3], } \\
1971\end{array}$ & 1 & 1 & 1 & 1 & 1 & & 1 & 1 & $? 1$ & & & 1 & & & \\
\hline Rolland et al [31], 1971 & 1 & 1 & 1 & 1 & 1 & & & & 1 & & 1 & & & 1 & \\
\hline Dennis and Bower [9], 1972 & 1 & 1 & 1 & 1 & 1 & & & 1 & & $? 1$ & 1 & 1 & 1 & 1 & 1 \\
\hline Hammami et al [13], 1972 & 1 & 1 & 1 & 1 & 1 & & 1 & & 1 & & & & 1 & 1 & \\
\hline Renier ex al [30], 1973 & 2 & 2 & 2 & 2 & 2 & & 1 & & 2 & & 1 & & & 1 & \\
\hline Gerhard ct al [12], 1973 & 1 & 1 & 1 & 1 & 1 & & & & I & & & & & 1 & \\
\hline Masson et al |21], 1973 & 1 & 1 & 1 & 1 & & 1 & & 1 & 1 & & 1 & & 1 & 1 & \\
\hline $\begin{array}{l}\text { Michalowicz and Wiszczor- } \\
\text { Adamczyk [26], } 1973\end{array}$ & 3 & 3 & 3 & 3 & 1 & 2 & & 2 & l & 2 & l & $\mathbf{l}$ & & 2 & \\
\hline Deodatice al $\{10\} .1974$ & 2 & 2 & 2 & 2 & 2 & & 1 & 2 & 2 & & & & 1 & 1 & \\
\hline $\begin{array}{l}\text { Tillman and von Bernuth } \\
\text { [39], 1975 }\end{array}$ & 2 & 2 & 2 & 2 & 2 & & 1 & 1 & 1 & $? 1$ & & 1 & & 2 & \\
\hline Dejong et al [8], 1976 & 1 & 1 & $\downarrow$ & I & 1 & & 1 & & 1 & & & & & 1 & \\
\hline Farietlo et al [11], 1977 & 6 & 6 & 6 & 6 & 6 & & 2 & 5 & 3 & 23 & & 1 & 3 & $? 1$ & 6 \\
\hline Bertoni et al (this report) & 4 & 4 & 4 & 4 & 3 & 1 & & 2 & 4 & & 3 & 2 & 2 & 3 & 4 \\
\hline Total & 43 & 43 & 43 & 43 & 37 & 6 & 15 & 19 & 33 & 10 & 22 & 9 & 10 & 27 & 15 \\
\hline
\end{tabular}

$N=$ number of cases; $F=$ temale; $M R=$ mental retardation; Seiz = seizures; $C R=$ chorioretiniris; Bil - bilateral; Uni $=$ unilateral; Col - coloboma; $M I C=$ microphthalmia: $\mathrm{ACC}=$ agenesis of the corpus; Tor = total; Par = partial; Het = hetcrotopias; Hemi = hemivertebrac: Hyps = hypsarrbythmia; $\mathrm{B}-\mathrm{S}=$ burst-suppression; ? = probable or questionable; PEG = pneumoencephalogran.

These findings contrast with the description of mental retardation and seizures present in all reported cases of Aicardi syndrome.

\section{Seizures}

All parients have had generalized seizures of both the myoclonic and tonic-clonic type (sometimes combined). The term spasms in flexion was used by Aicardi and by 10 other authors. The early onset of seizures ( 12 hours to 10 weeks of age in our patients, from birth to $31 / 2$ months in all other reports) is striking. Although the term spasms in flexion implies a specific seizure type, there has not been a diagnostic seizure pattern.

The seizures in the Aicardi syndrome are reportedly difficult to control, regardless of therapy. The use of prednisone or adrenocorticotropic hormone was mentioned in 13 reported cases; in 4 of these patients there was a decrease in seizure frequency, improvement of the EEG, or both. One of our patients (No. 4) was treated with prednisone $(30 \mathrm{mg}$ per day) with marked reduction in seizure frequency, and complete seizure control for more than a year was eventually attained with the use of standard anticonvulsants.

\section{Eye Lesions}

The specific eye lesion described by Aicardi is a chorioretinal lacuna, a punched-out lesion that was found to involve only the choroid layer according to fluoroscopic angiographic studies in 1 of Aicardi's original patients, with the retina itself being spared [13]. DeJong et al [8] found peripapillary annular depigmentation in the pigment epithelium associated with a defect in the sclera and a coloboma of the optic nerve. These lesions occur as multiple yellowish, central, round defects, up to six disc diameters across, and show less pigmentation than is usually observed in inflammatory chorioretinal changes; some have no pigmentation. The lesions are mostly bilateral (in 37 of 43 patients) and are frequently associated with microphthalmia ( 19 patients) or colobomas of the papilla or iris ( 15 patients). Other eye lesions are less common.

\section{Pneumoencephalographic Findings}

Total agenesis of the corpus callosum has been found in 29 of 39 previously reported patients, and 10 partial or questionable examples were also seen. Although all of Aicardi's patients had cortical heterotopias, this finding has been mentioned by only five other authors $[9,24,26,30,31]$. Total agenesis was diagnosed in all 4 of our parients, and 3 had recognizable heterotopias. Cortical heterotopias are demonstrable by pneumoencephalography if they are in a subependymal location, but if scattered subcortically, they may only be detected by autopsy [4] (this may explain why heterotopias are reported less 
frequently in nonautopsied cases of the Aicardi syndrome). The use of cerebral angiography has been reported only once and is not a useful diagnostic procedure in this condition [13].

Computed tomography has come to be recognized as a safe, precise, and noninvasive method to visualize agenesis of the corpus callosum [32]. However, most of the patients with Aicardi syndrome had already been described before this technique was introduced. The CT scan of Patient 4 (see Fig 4) did confirm the findings of the pneumoencephalogram, and thus CT scanning may be the preferred diagnostic technique in patients with suspected agenesis of the corpus callosum. No intracranial calcification was noted, either in the 39 patients previously reported or in this series.

\section{Vertebral Anomalies}

Hemivertebrae were found in 7 previously reported patients, and other costovertebral anomalies were described in 16, often associated with rib anomalies such as costal aplasias and dysplasias. All of our patients had vertebral anomalies, including hemivertebrae, fused vertebrae, spina bifida occulta, or variations in vertebral body size. None had rib anomalies.

\section{Electroencephalographic Findings}

Among the EEG features described in the Aicardi syndrome are: (1) hypsarrhythmia; (2) burst-suppression pattern, with varying degrees of asymmetry; (3) diffuse lateralized or bilateral shifting paroxysmal discharges (e.g., spike waves); and (4) diffuse or lateralized slowing of intrinsic activity. Some of these features were seen in all of the 12 EEGs performed in our 4 patients (Table 2). All these findings are nonspecific and are not pathognomonic for the Aicardi syndrome. Asymmetry is a nonspecific finding in cases of brain damage. Asyn- chrony of the EEG patterns in the two hemispheres is normal in the first months of life; absolute asynchrony was not seen in any of the EEGs in our series. Burst-suppression patterns occur in the LennoxGastaut syndrome as well as in metabolic disorders such as maple syrup urine disease or anoxia [17]. Asymmetry and asynchrony of EEG patterns have been found frequently in agenesis of the corpus callosum (mostly associated with background slowing and multifocal paroxysmal activity), but such patterns are not diagnostic [5]. It has been mentioned in one report [11] that sleep spindles are absent in the EEGs of Aicardi parients. However, we have identified sleep spindles whenever sleep recordings were obtained ( 10 of $12 \mathrm{EEGs)}$ in our patients. Although the sleep spindles were usually poorly formed, in a few instances they were physiologically well formed, were located centrally, and had an average frequency of $14 \mathrm{~Hz}$.

\section{Other Clinical Findings}

Variations in skull size and shape and in muscle tone are frequent in patients with the Aicardi syndrome. Sixteen of 39 previously reported patients and 2 of ours were microcephalic. Abnormal muscle tone was mentioned in 13 of the 39 prior patients and all 4 of ours.

\section{Family History}

Family histories in all present and reported cases are negative with respect to a complete Aicardi syndrome. A family history of seizures was mentioned for 3 of Aicardi's patients and in 1 other report [30]. Three examples of unspecified seizures, 1 of "muscular dystrophy," and 1 of hydrocephalus requiring replacement of the Holter valve were found in our family histories.

Tuble 2. EEG Findings in 4 Patients witb Aicardi Syndrome

\begin{tabular}{|c|c|c|c|c|c|c|c|}
\hline Patient & Age & $\begin{array}{l}\text { Degree of } \\
\text { Abnormality }\end{array}$ & Focality & Hypsarrhythmia & $\begin{array}{l}\text { Burst- } \\
\text { Suppression }\end{array}$ & Sleep & $\begin{array}{l}\text { Sleep } \\
\text { Spindles }\end{array}$ \\
\hline 1 & $\begin{array}{l}3 \mathrm{wk} \\
2 \mathrm{yr}, 3 \mathrm{mo} \\
2 \mathrm{yr}, 4 \mathrm{mo}\end{array}$ & $\begin{array}{l}\text { Moderate } \\
\text { Marked } \\
\text { Marked }\end{array}$ & $\begin{array}{l}\mathrm{L}>\mathrm{R} \\
\mathrm{R}>\mathrm{L} \\
\mathrm{R}>\mathrm{L}\end{array}$ & $\begin{array}{l}- \\
- \\
-\end{array}$ & $\begin{array}{l}- \\
+ \\
+\end{array}$ & $\begin{array}{l}+ \\
+ \\
+\end{array}$ & $\begin{array}{l}+ \\
+ \\
+\end{array}$ \\
\hline 2 & $312 \mathrm{mo}$ & Marked & $\mathrm{L}>\mathrm{R}$ & + & + & + & + \\
\hline 3 & $\begin{array}{l}3 \mathrm{mo} \\
12 \mathrm{mo}\end{array}$ & $\begin{array}{l}\text { Marked } \\
\text { Marked }\end{array}$ & $\begin{array}{l}\mathrm{L}>\mathrm{R} \\
\mathrm{L}>\mathrm{R}\end{array}$ & + & $\begin{array}{l}+ \\
-\end{array}$ & $\begin{array}{l}+ \\
+\end{array}$ & $\begin{array}{l}+ \\
+\end{array}$ \\
\hline 4 & $\begin{array}{l}4 \mathrm{mo} \\
8 \mathrm{mo} \\
1012 \mathrm{mo} \\
2 \mathrm{yr}, 10 \mathrm{mo} \\
4 \mathrm{yr}, 9 \mathrm{mo} \\
5 \mathrm{yr}, 10 \mathrm{mo}\end{array}$ & $\begin{array}{l}\text { Marked } \\
\text { Marked } \\
\text { Mild } \\
\text { Marked } \\
\text { Marked } \\
\text { Marked }\end{array}$ & $\begin{array}{l}\mathrm{R}>\mathrm{L} \\
\mathrm{R}>\mathrm{L} \\
\mathrm{L}>\mathrm{R} \\
\mathrm{L}>\mathrm{R} \\
\mathrm{L}=\mathrm{R} \\
\mathrm{L}>\mathrm{R}\end{array}$ & $\begin{array}{l}+ \\
- \\
- \\
+ \\
+ \\
+\end{array}$ & $\begin{array}{l}+ \\
- \\
- \\
- \\
- \\
-\end{array}$ & $\begin{array}{l}+ \\
+ \\
- \\
+ \\
- \\
+\end{array}$ & $\begin{array}{l}+ \\
+ \\
- \\
+ \\
- \\
+\end{array}$ \\
\hline
\end{tabular}




\section{Laboratory Studies}

The multiple negative studies for infectious agents performed in patients with the Aicardi syndrome are summarized in Table 3, which includes data from our 4 patients. Cerebrospinal fluid was reported to be normal in 20 patients in the literature. Renier, however, reported a pleocytosis ( 42 white cells $/ \mathrm{mm}^{3}$ ), with a protein concentration of $80 \mathrm{mg}$ per deciliter and an abnormal colloidal gold reaction [30]. The spinal fluid protein and glucose results were normal in 3 of our patients and were unavailable in the fourth.

\section{Timing of Intrauterine Insult}

In 11 of 39 previously reported cases that included histories, various disturbances of pregnancy were noted. Aicardi mentioned 3 "abnormal" pregnancies among his patients. Eight women were reported by

Table 3. Laboratory Data from Reported Cases of Aicardi Syndrome

\begin{tabular}{|c|c|c|c|c|c|c|c|c|}
\hline $\begin{array}{l}\text { Authors } \\
\text { and Year }\end{array}$ & $\mathrm{N}$ & $\operatorname{Toxo}^{\mathrm{a}}$ & $\mathrm{CID}^{\mathrm{a}}$ & Herp $^{a}$ & Ruba $^{a}$ & Sypha & Kary ${ }^{a}$ & Other \\
\hline $\begin{array}{l}\text { Aicardi et al }[1-3\rfloor \\
1965,1968,1969\end{array}$ & 15 & $0 / 15$ & $0 / 6$ & $0 / 7$ & $0 / 4$ & $0 / 9$ & $0 / 4$ & Urine AA chromatography $0 / 9$ \\
\hline $\begin{array}{l}\text { Léman et al [19], } \\
1968\end{array}$ & 1 & ND & ND & ND & ND & ND & ND & ND \\
\hline $\begin{array}{l}\text { Saraux et al [35], } \\
\quad 1969\end{array}$ & 1 & ND & ND & ND & ND & ND & ND & ND \\
\hline $\begin{array}{l}\text { Rousselie and Fon- } \\
\text { taine [33], 1971 }\end{array}$ & 1 & $0 / 1$ & ND & ND & ND & ND & $0 / 1$ & ND \\
\hline $\begin{array}{l}\text { Rolland et al [31], } \\
1971\end{array}$ & 1 & ND & ND & ND & ND & ND & ND & ND \\
\hline $\begin{array}{l}\text { Dennis and Bower } \\
{[9], 1972}\end{array}$ & 1 & $0 / 1^{b}$ & $0 / 1^{\circ}$ & ND & ND & ND & $0 / 1$ & $\begin{array}{l}\text { Negative viral cultures (urine, } \\
\text { throat, stool, CSF) }\end{array}$ \\
\hline $\begin{array}{l}\text { Hammami et al }[13] \text {, } \\
1972\end{array}$ & 1 & $0 / 1$ & $0 / 1^{\mathrm{d}}$ & $\mathrm{ND}$ & ND & $0 / 1$ & ND & \\
\hline $\begin{array}{l}\text { Renier et al }[30] \\
\quad 1973\end{array}$ & 2 & $0 / 2$ & $0 / 1$ & ND & $0 / 1$ & $0 / 2$ & $0 / 1$ & $\begin{array}{l}\text { TB stain test } 0 / 1, \text { brucellosis } 0 / 1 \\
\quad \text { listeriosis } 0 / 1\end{array}$ \\
\hline $\begin{array}{l}\text { Gerhard et al [12], } \\
1973\end{array}$ & 1 & $0 / 1$ & ND & ND & ND & ND & $0 / 1$ & \\
\hline $\begin{array}{l}\text { Masson et al [24] } \\
1973\end{array}$ & 1 & $0 / 1^{\mathrm{e}}$ & $0 / 1$ & $0 / 1$ & $0 / 1$ & ND & $0 / 1$ & Urine AA chromatography $0 / 1$ \\
\hline $\begin{array}{l}\text { Michalowicz and } \\
\text { Wiszczor- } \\
\text { Adamczyk [26], } \\
1973\end{array}$ & 3 & ND & ND & ND & ND & ND & ND & \\
\hline $\begin{array}{l}\text { Derodati et al [10], } \\
\quad 1974\end{array}$ & 2 & $0 / 2$ & $0 / 2$ & ND & $0 / 2$ & ND & ND & $\begin{array}{l}\text { Urine AA chromatography } 1 / 2, \\
\text { blood AA chromatography } 0 / 2\end{array}$ \\
\hline $\begin{array}{l}\text { Tillman and von } \\
\text { Bernuth }[391 \\
1975\end{array}$ & 2 & $0 / 2$ & ND & ND & ND & $0 / 1$ & ND & \\
\hline $\begin{array}{l}\text { Dejong et al [8], } \\
1976\end{array}$ & 1 & $0 / 1$ & $0 / 1$ & ND & ND & ND & ND & \\
\hline $\begin{array}{l}\text { Fariello et al [11], } \\
1977\end{array}$ & 6 & $0 / 1$ & $0 / 1$ & $0 / 1$ & $0 / 1$ & ND & $0 / 1$ & Normal dermatoglyphics \\
\hline $\begin{array}{l}\text { Bertoni et al (this } \\
\text { report) }\end{array}$ & 4 & $0 / 4$ & $0 / 4$ & $0 / 3$ & $0 / 3$ & $0 / 4$ & $0 / 1$ & $\begin{array}{l}\text { Viral cultures: blood } 0 / 1 \text {, urine } 0 / 1 \text {, } \\
\text { stool } 0 / 1 \text {, throat } 0 / 1 \text {, aqueous } \\
\text { humor } 0 / 1 \text {, urine } A A \text { chromatog- } \\
\text { raphy } 1 / 2\end{array}$ \\
\hline Total & 43 & $0 / 32$ & $0 / 18$ & $0 / 12$ & $0 / 12$ & $0 / 17$ & $0 / 11$ & \\
\hline
\end{tabular}

a Number of abnormalities found versus number of patients tested.

"Positive at $1: 4$.

'Positive at $1: 20$.

${ }^{d}$ Transiently positive at $1: 20$; mother positive at $1: 120$.

"Test done using aqueous humor.

$\mathrm{N}=$ number of cases; Toxo = toxoplasmosis; $\mathrm{CID}=$ cytomegalic inclusion disease; Herp $=$ herpes; Rub = rubella; Syph = syphilis; Kary = karyotypc; $\mathrm{CSF}=$ cerebrospinal fluid; $\mathrm{AA}=$ amino acids; $\mathrm{ND}=$ not done. 
others to have various nonspecific symptoms during pregnancy, including fever, abdominal pain, myalgia, vaginal bleeding, "grippe," diarrhea, and vomiting. In 3 of our patients, pregnancy complications included some of the following: hypertension, skin rash, abdominal pain, vaginal discharge, and mild peripheral edema.

The time of developmental arrest resulting in the features of the Aicardi syndrome appears to be no later than berween the fourth and twelfth weeks of gestation. The corpus callosum forms roughly from the third week to the end of the fifth month [20], beginning as a thickening in the lamina terminalis near the anterior commissure. A sufficient insult as late as the eighth week results in total agenesis, but milder and later perturbations produce various degrees of partial agenesis. Arrest of migrating neurons and glial cells moving from the periventricular zone results in heterotopias. Since these cellular migrations occur over a long period, heterotopias are not unique to any particular week of gestation.

In the fourth week of gestation, sclerotomes in the thoracic region divide transversely, and each resulting half joins half of the adjacent sclerotome to form the primitive vertebral body. Other sclerotomic cells migrate ventrolaterally and establish primordia of the ribs during the fifth week, but segmentation of the vertebral bodies is not completed until the period of cartilage formation, roughly from the seventh to the ninth week, after which time ossification centers appear [18]. However, it is uncertain whether anomalies such as hemivertebrae as seen roentgenographically can be specifically timed to a parricular period of development.

Of the series of events that take place in eye development, the closure of the choroid fissure can be fairly precisely timed in the seventh week. Failure of closure is termed coloboma and may involve not only the iris but the ciliary body, retina, choroid, and optic nerve [6]. It does not appear that anomalies such as microphthalmia or chorioretinal lesions can be safely attributed to any one time in development.

\section{Etiology}

The cause of the Aicardi syndrome remains unknown. No teratogenic drug or other toxin has yet been associated with this syndrome. The finding of generalized aminoaciduria in 2 of 20 patients is nonspecific, although elevated spinal fluid amino acids have been reported in a child with hereditary agenesis of the corpus callosum [25]. Only 9 patients with hereditary agenesis of the corpus callosum had been reported by 1973 [37]. The condition is transmitted as a recessive trait in mice [16]. In 1 sporadic case a patient with agenesis of the corpus callosum, mental retardarion, and seizures was found to have a chromosomal translocation [23]. A gene defect that is lethal to males has been proposed to explain female preponderance in the Goltz syndrome [38] and incontinentia pigmenti [21], which have features in common with the Aicardi syndrome. The normal karyograms cannot exclude the possibility that abnormal cells were once present in a mosaic pattern but subsequently died [28]. It is also possible that an environmental insult could be lethal in males only. Although infections can induce symmetrical noninflammatory defects that appear as primary insults in neuroembryogenesis [15] and agents such as toxoplasmosis may often strike during the first trimester [29], no infectious agent can be implicated in the Aicardi syndrome. The false-negative rates are now sufficiently low (e.g., 10 to $15 \%$ for agents such as toxoplasmosis [29]) that coincidental test failure in all cases is unlikely. Sabin and Feldman [34] had originally classified a group of chorioretinitis patients with negative dye tests as having "pseudotoxoplasmosis" but later found most of them to be cytomegaloviruspositive (Feldman HA: personal communication, 1973).

Recent work by Hempel et al [14] demonstrated that intracutaneous injection of autologous retina with adjuvant was followed by chorioretinitis with massive infiltration of the choroidal tissue and histological destruction of the photoreceptor layer in rabbits. The finding suggests that maternal antibodies may selectively affect the developing eye and raises the possibility of immune mechanisms operating to produce the Aicardi syndrome. Maternal hypoxia, induced by only four to five hours of lowered atmospheric pressure during specific periods of early pregnancy, has been associated with hemivertebrae and other vertebral fusion anomalies as well as rib anomalies in the fetal rabbir [7] and mouse [27].

Supported in part by funds provided by a Michigan Department of Public Health grant to the Section of Pediatric Neurology, University of Michigan Medical Center.

The authors are grateful to K. A. Kooi, MD, R. P. Tucker, MD A. G. Clague, MD, and T. O. Gabrielsen, MD, for their helpful advice. Catherine Mazzolini assisted in preparation of the manuscript.

\section{References}

1. Aicardi J, Chevrie J : Le syndrome agénésie calleuse, spasmes en flexion, lacunes chorio-rétiniennes. Arch Fr Pediatr $26: 809-810,1969$

2. Aicardi J, Chevrie JJ, Rousselic F: Le syndrome spasmes en flexion, agénésie calleuse, anomalies chorio-rétiniennes. Arch Fr Pediatr 26:1103-1120, 1969

3. Aicardi J, Lefebvre $J$, Lerique-Koechlin A: A new syncirome: spasms in flexion, callosal agenesis, ocular abnormalities. Elecroencephalogr Clin Neurophysiol 19:609-610, 1965

4. Bergeron RT: Radiographic demonstration of cortical heterotopia. Acta Radiol (Diagn] (Stockh) 9:135-139, 1969) 
5. Carpenter MB, Druckemiller WH: Agenesis of the corpus callosum diagnosed during life. Arch Neurol Psychiatry 69:305-322, 1953

6. Corliss CE: Age, growth, and changes in the external form of the body, in Jeffers JD, Marshall DJ (eds): Patcen's Human Embryology. New York, McGraw-Hill, 1976

7. Degenhardt KH, Knoche E: Analysis of intrauterine malformation of the vertebral column induced by oxygen deficiency. Can Med Assoc J 80:441-445, 1959

8. DeJong JGY, Delleman JW, Houben M, et al: Agenesis of the corpus callosum, infantile spasms, ocular anomalies (Aicardi"s syndrome). Neurology (Minneap) 26:1152-1158, 1976

9. Dennis J, Bower BD: The Aicardi syndrome. Dev Med Child Neurol 14:382-390, 1972

10. Deodati $F, B e c P$, Carrière JP, et al: Le syndrome d'Aicardi. Arch Ophtalmol (Paris) 34:8-22, 1974

11. Fariello RG, Chun RWM, Doro JM, et al: EEG recognition of Aicardi's syndrome. Arch Neurol 34:563-566, 1977

12. Gerhard JP, Juif JG, Luckel JC, et al: À propos d'une nouvelle observation de syndrome de spasm en flexion, agénésie calleuse er anomalies chorio-rétiniennes (syndrome d'Aicardi). Bull Mem Soc Fr Ophtalmol 73:363-366, 1973

13. Hammami $H$, Streiff EB, DeWolff E: Contribution à la connaissance du syndrome d'Aicardi et coll. Bull Mem Soc Fr Ophtalmol 85:598-614, 1972

14. Hempel E, Tilgner S, Meyer W, et al: Fxperimental chorioretinitis in rabbits following injection of autologous retina in Freund's complete adjuvant. Exp Fye Res 23:399401, 1976

15. Johnson RT: Effects of viral infection on the developing nervous system. N Engl J Med 287:599-604, 1972

16. King LS: Hereditary defects of corpus callosum in mouse, Mus musculus. J Comp Neurol 64:337-363, 1936

17. Kooi KA: Metabolic and endocrine disorders, in Fundamentals of Electroencephalography, New York, Harper \& Row, 1971

18. Langman J: Skelctal system and ossification, in Medical Embryology. Third edition. Baltimore, Williams \& Wilkins, 1975

19. Léman $P$, Loiseau $P$, Leifer $C$ : Sur un case de syndrome de West avec agénésie du corps calleux, anomalies oculaires. Ann Med Psychol (Paris) 126:465-466, 1968

20. Lemire RJ, Loeser JD, Leech RW, et al: Normal and Abnormal Devclopment of the Human Nervous System. Hagerstown, MD, Harper \& Row, 1975

21. Lenz von W: Zur Genetik der Incontinentia pigmenti. Ann Paediatr 196:149-165, 1961

22. Loiseau $P$, Théodoridès $M$, Leifer $C$, et al: $\dot{A}$ propos d'un nouveau cas, associant un syndrome de West, une agénésie du corps calleux et des anomalies oculaires. Arch Fr Pediatr $25: 833,1968$
23. Mantle DJ, Mitchell P, Kucheria K, et al: A mentally retarded child with convulsions, agenesis of the corpus callosum, and a translocation involving chromosome 2 and the B group. J Med Genet 6:435-437, 1969

24. Masson M, Nirrengarten A, Gerhard JP, et al: Le syndrome spasmes en flexion, agénésie calleuse, anomalies choriorétiniennes. Pediatrie 5:527-531, 1973

25. Menkes JH, Philippart M, Clark DB: Hereditary partial agenesis of corpus callosum. Arch Neurol 11:198-208, 1964

26. Michalowicz R, Wiszczor-Adamczyk B: Agenesia of corpus callosum, ocular anomalies, and salaam seizures (Aicardi's syndrome). Neurol Ncurochir Pol 7:785-792, 1973

27. Murakami U, Kameyama $Y$ : Vertebral malformation in the mouse fetus caused by maternal hypoxia during eariy stages of pregnancy. J Embryol Exp Morphol 11:107-118, 1963

28. Nichols WW: Virus induced chromosome abnormalities. Annu Rev Microbiol 24:479-500, 1970

29. Remington JS, Klein J: Toxoplasmosis and cytomegalovirus, in Remington JS (ed): Infectious Disease of the Fetus and Newborn Infant. Philadelphia, Saunders, 1976

30. Renier W, Gabreels F, Mol L, et al: Agenesis of the corpus callosum, chorioretinopathy and infantile spasms (Aicardi syndrome). Psychiatr Neurol Neurochir 76:39-45, 1973

31. Rolland JC, Anizan B, Laugier J, et al: Syndrome des spasmes en flexion avec agénésic calleuse et anomalies choriorétiniennes. Arch Fr Pediatr 28:251, 1971

32. Rothner AD, Duchesneau PM, Weinstein M: Agenesis of the corpus callosum revealed by computerized tomography. Dev Med Child Neurol 18:160-166, 1976

33. Rousselie F, Fontaine M: Anomalies chorio-rétiniennes: spasmes en flexion. Agenesie calleuse. Arch Ophtalmol (Paris) $31: 539-546,1971$

34. Sabin AB, Feldman HA: Chorioretinoparhy associated with other evidence of cerebral damage in childhood. J Pediatr $35: 296-309,1949$

35. Saraux H, Biais B, Chatellier P: Anomalies oculaires et malformations des structures médianes du cerveau antérieur. Ann Oculist (Paris) 202:241-257, 1969)

36. Savitsky E, Spinelli VA: Agenesis of corpus callosum in infancy: clinical and roentgenologic aspecrs. Am $J$ Dis Child 76:109-115, 1948

37. Shapira Y, Cohen T: Agenesis of corpus callosum on two sisters. J Med Genet 10:226-269, 1973

38. Smith DW: Recognizable Patterns of Human Malformation. Generic, Embryologic and Clinical Aspects. Philadelphia, Saunders, 1970

39. Tillmann W, von Bernuth $\mathrm{H}$ : Das Aicardi-Syndrom. Klin Monatsbl Augenheilkd 167:496-499, 1975 